\title{
A Dynamic Econometric Modelling of the Determinants of Capital Structure of Listed Companies- A Mauritian Perspective
}

\author{
Dharveshsingh Gourdeale $^{1}$ and Virendra Polodoo ${ }^{2}$ \\ ${ }^{1,2}$ Amity Institute of Higher Education \\ Correspondence: Virendra Polodoo, School of Economics and Finance, Amity Institute of Higher Education, Mindspace \\ Building, Ebene, Mauritius.
}

Received: March 31, 2016

Accepted: April 20, $2016 \quad$ Available online: April 22, 2016

doi:10.11114/aef.v3i3.1567

URL: http://dx.doi.org/10.11114/aef.v3i3.1567

\begin{abstract}
The gist of this paper is to empirically assess the determinants of capital structure decisions for 29 listed firms on the Stock Exchange of Mauritius for the period spanning 2006-2014. The paper employs the random coefficient estimation, deemed to be a novelty in the econometric literature to test for the dynamism of the model. According to the random coefficient estimates, the important determinants of leverage in Mauritius are profitability, liquidity, tangibility, growth opportunities and size. Business risk and age do not appear to have any significant effect on capital structure. The findings of the study offer several implications for policy making. Government policies aimed at developing the domestic bond market would be welcome as Mauritian firms face a shortage of funding options and heavy reliance on short term debt. Further governmental plans to boost the fluidity of equity issues and to reduce the associated costs are also advocated.
\end{abstract}

Keywords: capital structure, dynamism, random coefficient estimation, determinants of leverage

\section{Introduction}

Most capital structure studies have sought to assess the relevance of theories such the pecking order theory, trade- off theory among others but also to analyze the explanatory power of the determinants of capital structure. As such, finance literature highlights profitability, size, growth, tangibility and liquidity amongst others as the most important explanatory variables. Nevertheless, according to Demirguc-Kunt and Maksimovic (1996), one determinant which has been largely neglected in literature is equity market development. Indeed, there have been limited attempts to investigate the link between the stock market development and capital structure decisions. De facto, corporate finance theory posits that companies target an optimal capital structure in order to reduce economic costs that arise from taxes and other market imperfections. Development of financial markets may lead to a decrease in monitoring costs and consequently reduce the cost of both equity and debt through synergistic reactions. This leads to the conclusion that a relationship between financial market development and financing decisions does exist. In terms of empirical studies incorporating the dynamic effects of equity market development in capital structure decisions, one can mention the works of Padachi and Seetanah (2007) and Seetanah et al. (2007) as being the only prominent studies in the Mauritian context. The Mauritian financial market has witnessed considerable transformations post 2006 and this paper is an attempt to produce up to date evidences for a period of time not covered in existing literature. In addition, this study is appropriate in the Mauritian context because local managers have flexibility in selecting their capital structure.

The paper is different to past studies in that it uses the Random coefficient model as a supplementary and experimental test for analyzing the significance of the variables chosen in the research and as a robustness check against the results obtained from the GMM analysis. Applicable accounting standards offer a wide range of acceptable accounting treatments and thereof accounting choices and estimates are not standardized but dependent on specific management decisions. The choiceness of the Random coefficient model lies in the fact that its results encompass these accounting differences.

In their pioneering paper in 1958, Modigliani and Miller (MM) postulate that in a world of perfect markets, where there are no taxes, perfect dissemination of information and no transaction costs attached with raising money or becoming bankrupt, the percentage of debt constituting a company's capital structure will have no effect whatsoever on the firm's value. MM suggest that investors are rational and as such the required return of equity is positively correlated with the 
gearing level. Nevertheless, it is blatant that the assumptions associated with the first proposition make it less realistic. In an effort to remedy to those limitations, Modigliani and Miller (1963) thereof come up with a revised theory which limits the perfect capital market assumptions by incorporating the corporate tax system which gives tax relief on interest payments.

Theories pertaining to the determinants of capital structure have essentially focused on tangibility, size, profitability, growth, liquidity, age, business risk, and stock market and banking sector development. The agency cost theory postulates that tangibility has a positive correlation with leverage. From a lender's point of view, a firm with a high level of fixed assets is less risky to lend to because its assets can be used as collateral. Contrarily, if a company's balance sheet is made up primarily of intangible assets, monitoring expenses (agency costs) for the lender are going to be higher. However it is worth noting that the studies suggesting that lenders are willing to sanction loans to firms with a high level of tangible assets are based on the developed nations (Harris and Raviv, 1990, Rajan and Zingales, 1995 and Wald, 1999). Contrariwise, Wiwattanakantang (1999), Um (2001) and Booth et al. (2001), and Huang and Song (2002) observe that in developing countries, tangible assets trigger a negative effect on leverage.

A positive relationship between size and leverage is promulgated by the trade-off theory. Nevertheless, as Rajan and Zingales (1995) point out, if the costs of financial distress are low, then the significance of this positive relationship is weaker. Agency cost theory also advocates that size triggers a positive effect on leverage. Large companies have a preference for long-term debt while smaller firms are likely to be dependent on short-term debt (Marsh, 1982). Previous investigation into the size and capital structure relationship has generated mixed results. Studies which support that size and leverage share a positive relationship are Rajan and Zingales (1995) for all G7 countries except for Germany, Wald (1999), Bevan and Danbolt (2000), Pandey (2001) and Frank and Goyal (2004). Contrariwise, Titman and Wessels (1988) and Chaplinsky and Niehaus (1993) delineate how size generates a negative effect on debt-equity ratios.

Profitable firms depend on debt because they know they can use the profits to pay their debts. Myers and Majluf (1984) suggest that firms choose internally generated funds compared to alternative funding options due to the existence of asymmetric information. Hence, profitable companies prefer internal earnings over debt financing. Authors like Titman and Wessels (1988), Rajan and Zingales (1995) and Bevan and Danbolt (2002) in developed nations and Wiwattanakantang (1999), Booth et al. (2001), Pandey (2001), and Chen (2004) in developing countries affirm that profits trigger a negative impact on leverage.

Moreover, the literature posits a negative relationship between leverage and growth opportunities. Firms in quest of growth are likely to undertake risky projects because they can potentially boost the growth of a company. After all, higher risk is often synonymous to higher rewards. Thus, banks and other lenders may be reticent to sanction loans to such companies because of the excessive risk attached. Jensen and Meckling (1976), Titman and Wessels (1988), Rajan and Zingales (1995) and Barclay and Smith (1996) observe a negative association between growth rate and the level of long-term debt. It is postulated that high-growth firms often use up their internal funds and they consequently resort to debt which hints at a positive correlation between debt-equity ratios and growth. In terms of empirical studies, Booth $e t$ al. (2001) show a positive association between growth rate and leverage in a few models. Myers (1984) and Bevan and Danbolt (2001) in addition conclude that short-term debt has a positive link with growth opportunities.

Furthermore, firms with amassed cash and liquid assets will choose their internal earnings over borrowing as far as funding is concerned. This negative relationship between liquidity and debt-equity ratios is continuously depicted in empirical studies like Deesomsak, Paudyal and Pascetto (2004) and De Jong, Kabir and Nguyen (2008). Anderson (2002) reports a positive relationship between liquidity and leverage and this can be written down to the precautionary motive in holding liquid assets for firms with high long term debts. Another rational explanation is that creditors view liquidity as a measure of a firm's ability to meet its short-term debt obligations whenever they fall due. Consequently, a firm with an attractive characteristic such as high liquidity should have no problems in having access to debt financing.

Diamond (1984) affirms that firms capitalize on their reputation developed over the years to position themselves as being credit worthy. This is consistent with the trade-off theory. Nguyen (2010) and Shehu (2011) suggest that as a firm grows for a sustained period, it installs itself as a going-concern and thereof boosts its ability to incur more debts. Ergo, age generates a positive effect on leverage. Conversely, the Pecking order theory hypothesizes a negative relationship between age and debt. As a firm matures and establishes its goodwill in the market, it will manage its cash flows more efficiently and thence increase profits. Moreover, according to Bell and Vos (2009) a mature firm can accumulate internal funds over time and has more access to equity markets which collectively result in reduced reliance on debt.

According to Kate et al. (1991), the level of risk is a fundamental determinant of a firm's capital structure. Business risk is synonymous to the volatility in the earnings of a business and is a measure of financial distress. Johnson (1997) reports that firms with unpredictable earnings growth may face a situation where debt servicing becomes difficult that is cash inflows are not sufficient to meet financial obligations. Both the Pecking order theory and trade off theory postulate that volatility has a negative relationship with leverage. 
Last, but not least, research by Demirguc-Kunt and Maksimovic (1996) demonstrate that the initial improvements witnessed in a developing stock market generate increased demand for investment and this is translated into more business for banks as well through synergism. At initial stages of stock market development, equity and debt are therefore complements. Contrariwise for developed stock markets, further development is synonymous to the replacement of debt funding by equity. There is a thence a substitution effect. The economic setting and the stage of development of financial markets are wherefore crucial considerations.

Turning to empirical studies, Demirguc-Kunt and Maksimovic (1996), as pioneers, report a positive relationship between stock market development and debt-equity ratios for developing nations while stock market expansion has a negative impact upon debt for developed countries. A positive and significant correlation between leverage and banking sector development is also found for a sample aggregating firms from developed and developing countries. In line with the aforementioned research, Giannetti (2003) reveals that firms are more geared in countries where the stock market is relatively less developed. Contrarily, empirical researchers such as Agarwal and Mohtadi (2004), Joeveer (2006) and Bokpin (2010) highlight a negative correlation between stock market development and leverage.

In the Mauritian context, Padachi and Seetanah (2007) based on static panel estimates show that stock market expansion is positively related to debt financing for non-financial firms while financial firms replace debt with equity. A positive association is also observed between the size of the banking sector and debt-equity ratios. Seetanah et al. (2007) outline a positive relationship between debt financing and further expansion of the market in general based on dynamic panel estimates. More details about the past and pertinent empirical researches can be obtained from Table 1.

Table 1. Summary of prominent empirical research

\begin{tabular}{|c|c|c|c|c|c|}
\hline Author & $\begin{array}{c}\text { Period } \\
\text { covered }\end{array}$ & Aim of the studies & Sample & Models & $\begin{array}{l}\text { Relevant outcomes of the } \\
\text { research }\end{array}$ \\
\hline $\begin{array}{l}\text { Demirguc-Kunt } \\
\text { and } \\
\text { Maksimovic } \\
(1995)\end{array}$ & 1980-1991 & $\begin{array}{l}\text { The analysis of the effects of } \\
\text { stock market development on } \\
\text { firm's capital structure } \\
\text { decisions. }\end{array}$ & $\begin{array}{l}30 \\
\text { developing } \\
\text { and } \\
\text { industrial } \\
\text { nations }\end{array}$ & Static models & $\begin{array}{l}\text { A negative correlation } \\
\text { between leverage and stock } \\
\text { market development is } \\
\text { reported for the aggregate } \\
\text { sample. }\end{array}$ \\
\hline
\end{tabular}

Giannetti

(2003)

Agarwal and

Mohtadi (2004)

1980-1997 An investigation of the relationship between stock market development and economic growth.

Joeveer (2006)

1995-2002 An assessment of the significance of firm-specific, country, institutional and macroeconomic factors in determining financing choices.

34

Bokpin (2010)

1990-2006 financial market development on financing decisions of
9 Eastern

European countries

26

European

21 emerging

Dynamic method.

nations

emerging nations
ANOVA analysis A negative relationship
between stock market
expansion and debt-equity
ratios is postulated.

Firms incur more debts in nations where stock markets are under-developed.

A negative relationship between debt and stock market development is highlighted.

The model of

A negative relationship between further development of the financial market and 


\begin{tabular}{|c|c|c|c|c|c|}
\hline & & $\begin{array}{l}\text { emerging nations' firms to } \\
\text { find whether or not } \\
\text { interactions in the financial } \\
\text { market affects available choice } \\
\text { of funding of firms. }\end{array}$ & & $\begin{array}{l}\text { and the pooled } \\
\text { mean group } \\
\text { estimator }\end{array}$ & leverage is reported. \\
\hline $\begin{array}{l}\text { Padachi and } \\
\text { Seetanah } \\
(2007)\end{array}$ & $1994-2005$ & $\begin{array}{l}\text { Probe into the relationship } \\
\text { between stock market } \\
\text { development and capital } \\
\text { structure decisions. }\end{array}$ & $\begin{array}{l}38 \text { listed } \\
\text { firms on the } \\
\text { Mauritian } \\
\text { stock } \\
\text { market }\end{array}$ & $\begin{array}{l}\text { Cross-country and } \\
\text { pooled OLS } \\
\text { estimates and } \\
\text { Static panel data } \\
\text { estimates }\end{array}$ & $\begin{array}{l}\text { Static panel estimates show } \\
\text { that stock market expansion is } \\
\text { related to debt financing for } \\
\text { non-financial firms while } \\
\text { financial firms have been } \\
\text { found to replace debt with } \\
\text { equity }\end{array}$ \\
\hline $\begin{array}{l}\text { Seetanah et al. } \\
\text { (2007) }\end{array}$ & 1994-2006 & $\begin{array}{l}\text { Probe into the relationship } \\
\text { between stock market } \\
\text { development and capital } \\
\text { structure decisions. }\end{array}$ & $\begin{array}{l}38 \text { listed } \\
\text { firms on the } \\
\text { Mauritian } \\
\text { stock } \\
\text { market }\end{array}$ & $\begin{array}{c}\text { Static and } \\
\text { dynamic panel } \\
\text { data (GMM) } \\
\text { estimates }\end{array}$ & $\begin{array}{l}\text { Outcomes from the GMM } \\
\text { estimates of both financial } \\
\text { and non-financial firms point } \\
\text { at the existence of a positive } \\
\text { relationship between debt } \\
\text { financing and further } \\
\text { expansion of the equity } \\
\text { market }\end{array}$ \\
\hline
\end{tabular}

Source: Authors' own display.

\section{Method}

The secondary data collected covered a sample of 29 firms listed on the Stock Exchange of Mauritius (SEM) for a period of nine years (2006-2014) with a total of 261 observations. The companies' financial statements end as at $31^{\text {st }}$ March, $30^{\text {th }}$ June or $31^{\text {st }}$ December but this is not an obstacle as long as a 12 months period is covered. The firms are broken down into financial and non-financial firms for the GMM analysis. The reasoning is that financial institutions tend to be regulated differently in terms of their capital adequacy requirements and their accounting treatments may differ from non-financial companies. Considering that part of the data collected appeared skewed, log transformation has been applied on some variables (such as age and sales) to generate normality. The data used in this paper was obtained from World Bank and SEM handbooks 2010 and 2015.

The econometric model is given as follows:

$L E V E R=\alpha+\beta 1 R O A+\beta 2 S I Z E+\beta 3$ TANG $+\beta 4$ GROWTH $+\beta 5$ RISK $+\beta 6 L I Q++\beta 7$ STOCK $+\beta 8$ BANK $+\beta 9$ $A G E+U t$

Leverage (LEVER) is the dependent variable and return over asset (ROA), size (SIZE), tangibility (TANG), growth opportunities (GROWTH), volatility (RISK), liquidity (LIQ), stock market development (STOCK), age (AGE) and banking sector expansion (BANK) are the independent variables. $\beta 1, \beta 2, \beta 3, \beta 4, \beta 5, \beta 6, \beta 7, \beta 8$ and $\beta 9$ are the estimated parameters and Ut is the residual error term.

Capital structure decisions are dynamic by nature. They change overtime as managers rebalance the financing structure of their firms to better suit their needs at different points in time. In regards to methodology, according to Seetanah et al. (2014), the dynamic panel GMM estimator removes bias by integrating dynamic endogeneity and catering for simultaneity while removing unobservable heterogeneity. According to Seetanah et al. (2007), second-step GMM has a problem of downward bias and thereof first-step GMM is advocated. Hondroyiannis et al. (2005) advocate that Random Coefficient (RC) estimates give better results than both the OLS and GMM. RC is called the Time Varying Model as it permits the intercepts and slopes to vary across companies, through time and at a particular point in time. Moreover, there is no requirement to incorporate dummy variables to consider omitted variables and it tackles problems like endogeneity coupled with measurement errors. The superiority of the random coefficient model lies in the fact that in addition to dynamism, it incorporates the fact that the listed firms being studied have different accounting policies.

A summary of the variables is provided below.

The measure of debt/leverage used in this study is the total debt ratio which encompasses both long-term liabilities (debts repayable within more than one accounting period) and current liabilities like bank overdraft and loans that need to be paid within a year, etc. To circumvent potential heteroscedasticity problems, the dependent variable is deflated by the book value of total equity which is line with Bevan and Danbolt (2002). In addition, according to Harvey et al. (2004), firms are probably more interested in book value leverage as the bank loan arrangement normally deals with 
book value rather than market value.

In addition to leverage, the independent variables employed in the model and the ways they are calculated are depicted in Table 2. Table 3 shows the theoretical predicted signs coupled with the related empirical researches.

Table 2. Computation Methods

\begin{tabular}{lcc}
\hline No. & Variable & Measurement \\
\hline 1 & Total debt & Total debt/Total Debt + Total Equity \\
2 & Age & Natural logarithm of ( Last observed year- Incorporation year) \\
3 & Asset tangibility & Fixed Assets/ Total Assets \\
4 & Growth opportunities & Growth of Total Assets \\
5 & Liquidity & Current assets/ Current Liabilities \\
6 & Volatility & Absolute value of the variation in ROA. \\
7 & Profitability & Operating profit/ Total Assets \\
8 & Size & Natural Logarithm of Sales or Revenue \\
9 & Stock market expansion & Market capitalization ratio+ Total value of shares traded ratio \\
& Banking sector & 2 \\
\cline { 2 - 2 } 10 & Development & 2 \\
& Bank's liquid liabilities to GDP + The ratio of private credit to GDP \\
\hline
\end{tabular}

Source: Authors' own display

Table 3. Output of past research

\begin{tabular}{|c|c|c|}
\hline Variables & $\begin{array}{l}\text { Correlation coefficient with } \\
\text { debt-equity ratios }\end{array}$ & Empirical Evidences \\
\hline \multirow[t]{2}{*}{ Profitability } & Positive & Brown et al. (1982), Li et al. (1992) \\
\hline & Negative & $\begin{array}{l}\text { Toy et al. (1974), Rajan and Zingales (1995), Fama and French } \\
\text { (2002), Nguyen (2010) }\end{array}$ \\
\hline \multirow[t]{2}{*}{ Size } & Positive & Warner (1977), Rajan and Zingales (1995), Forsberg (2004) \\
\hline & Negative & Titman and Wessels (1985), Li et al. (2011) \\
\hline \multirow[t]{2}{*}{ Tangibility } & Positive & $\begin{array}{l}\text { Myers (1984), Rajan and Zingales (1995), Frank and Goyal } \\
\text { (2002) }\end{array}$ \\
\hline & Negative & Grossman and Hart (1982), Wijst and Thurik (1993) \\
\hline \multirow[t]{2}{*}{ Growth } & Positive & Chen (2004), Nguyen (2010) \\
\hline & Negative & Ross (1977), Rajan and Zingales (1995), Ozkan (2001) \\
\hline Volatility & Negative & Walsh and Ryan (1997), Wald (1999), Seetanah et al. (2007) \\
\hline Liquidity & Negative & $\begin{array}{l}\text { Rajan and Zingales (1995), Panno (2003), Deemosak et al. } \\
\text { (2004) }\end{array}$ \\
\hline Age & Positive & Barton et al. (1989), Abel (2007) \\
\hline
\end{tabular}


Negative

Stock market Positive

Development

Development

Negative
Odit (2011), Bell and Vos (2009)

Gianetti (2003), Seetanah et al. (2007)

Agarwal \& Mohtadi (2004), Joeveer (2006), Bokpin ( 2010)

Demirguc-Kunt and Maksimovic ( 1996), Agarwal \& Mohtadi (2004)

Source: Author's own display

\section{Discussion}

An important consideration before making the suitable model specification is to test the stationarity of the variables. The Im, Pesaran and Shin (1995) panel unit root tests are conducted on the dependent and explanatory variables. The panel unit root results applied on the time series in levels reject the null hypothesis in favour of stationarity at $10 \%$ significance level for each variable. The results are in line with the Fisher-ADF and Fisher-PP panel unit root tests. On that account, it is judged safe to work with the variables directly. After testing for stationarity, GMM estimates are produced as follows:

Table 4. Dynamic Panel Data Estimation (First Step GMM estimator)

\begin{tabular}{|c|c|c|c|}
\hline Variables & $\begin{array}{c}\text { Aggregate Sample } \\
\text { Dynamic Panel } \\
\end{array}$ & $\begin{array}{c}\text { Non-financial Firms } \\
\text { Dynamic Panel }\end{array}$ & $\begin{array}{l}\text { Financial Firms } \\
\text { Dynamic Panel } \\
\end{array}$ \\
\hline TDR lag (1) & $\begin{array}{c}0.405 * * * \\
(0.000)\end{array}$ & $\begin{array}{c}0.593 \\
(0.108)\end{array}$ & $\begin{array}{c}0.243 \\
(0.684)\end{array}$ \\
\hline$\Delta$ Profitability & $\begin{array}{c}0.053 * * * \\
(0.007)\end{array}$ & $\begin{array}{l}1.390^{* *} \\
(0.044)\end{array}$ & $\begin{array}{l}-0.072 \\
(0.499)\end{array}$ \\
\hline$\Delta$ Size & $\begin{array}{c}0.014 * * * \\
(0.000)\end{array}$ & $\begin{array}{l}0.077 * \\
(0.055)\end{array}$ & $\begin{array}{l}-0.007 \\
(0.677)\end{array}$ \\
\hline$\Delta$ Tangibility & $\begin{array}{c}-0.143 * * * \\
(0.000)\end{array}$ & $\begin{array}{c}-0.697 * * \\
(0.022)\end{array}$ & $\begin{array}{c}0.016 \\
(0.887)\end{array}$ \\
\hline$\Delta$ Risk & $\begin{array}{l}-0.034 \\
(0.296)\end{array}$ & $\begin{array}{l}3.031^{* *} \\
(0.024)\end{array}$ & $\begin{array}{c}0.499 \\
(0.371)\end{array}$ \\
\hline$\Delta$ Growth & $\begin{array}{c}0.016 \\
(0.116)\end{array}$ & $\begin{array}{l}0.069^{*} \\
(0.081)\end{array}$ & $\begin{array}{l}-0.048 \\
(0.241)\end{array}$ \\
\hline$\Delta$ Stock & $\begin{array}{c}0.113 * * * \\
(0.000)\end{array}$ & $\begin{array}{l}0.498^{* *} \\
(0.015)\end{array}$ & $\begin{array}{l}-0.013 \\
(0.836)\end{array}$ \\
\hline$\Delta$ Bank & $\begin{array}{c}0.023 \\
(0.339)\end{array}$ & $\begin{array}{l}1.017 * * \\
(0.039)\end{array}$ & $\begin{array}{l}-0.348 \\
(0.256)\end{array}$ \\
\hline$\Delta$ Age & $\begin{array}{c}0.081 * * * \\
(0.007)\end{array}$ & $\begin{array}{l}-1.301 \\
(0.113)\end{array}$ & $\begin{array}{c}0.589 \\
(0.303)\end{array}$ \\
\hline$\Delta$ Liquidity & $\begin{array}{c}-0.001 * * * \\
(0.000)\end{array}$ & $\begin{array}{l}-0.051 \\
(0.353)\end{array}$ & $\begin{array}{l}-0.001 \\
(0.525)\end{array}$ \\
\hline$\Delta$ Constant & $\begin{array}{c}0.045 \\
(0.677)\end{array}$ & $\begin{array}{r}4.310^{* *} \\
(0.022)\end{array}$ & $\begin{array}{l}-1.571 \\
(0.338)\end{array}$ \\
\hline Observations & 232 & 112 & 120 \\
\hline $\begin{array}{l}\text { Sargan Test of } \\
\text { Overidentifying restrictions }\end{array}$ & prob $>$ chi $2=0.9474$ & prob $>$ chi $2=1$ & prob $>$ chi $2=1$ \\
\hline $\begin{array}{l}\text { Arellano-Bond test of } \\
\text { 1st order autocorrelation }\end{array}$ & prob $>$ chi $2=0.1524$ & prob $>$ chi $2=0.8465$ & prob $>$ chi $2=0.401$ \\
\hline $\begin{array}{l}\text { Arellano-Bond test of } \\
\text { 2nd order autocorrelation }\end{array}$ & prob $>$ chi $2=0.1534$ & $\ldots$. & prob $>$ chi $2=0.8768$ \\
\hline
\end{tabular}

Source: Stata 12

The values in bracket are synonymous to the z-statistic and ***,** and * show significance at the 1\%, 5\% and $10 \%$ levels respectively.

For all the 3 dynamic panel data sets, the p-values of the Sargan test are greater 0.1, so the recommendation is to accept that over-identifying restrictions are invalid and to conclude that there is no model misspecification. The purpose of 
Arellano Bond test is to assess the non-randomness in data. If the randomness assumption does not hold, then the use of a different model is advocated. All first order autocorrelation tests are greater than 0.1 , so it can be concluded that there is no autocorrelation with the error terms. When there is no first order serial correlation, there are automatically no second orders as well.

From the aggregate sample in Table 4, the positive and statistically significant coefficient of the lagged dependent variable (leverage) indicates that financing decisions are dynamic by nature in Mauritius. It also suggests that firms adjust to a specific leverage ratio. According to Gaud et al. (2005), if a target leverage ratio exists, then firms should take the right courses of action to attain it. The value of $\lambda$ obtained is 0.595 (1- 0.405) and this hints at an improvement in the adjustment process compared to the 0.36 obtained by Seetanah et al. (2007). In regards to achieving the preferred leverage ratio, it is worth noting that the coefficient $\lambda$ has an inverse relationship with adjustment costs.

Thence, the $\lambda$ derived hint at lower adjustment costs in Mauritius for the period 2006 to 2014 compared to the period covered by Seetanah et al. (2007) which is 1994 to 2006. The issue of new shares on the Mauritian market has not always been fluid due to considerable bureaucracy and due to the uncertainty generated by market imperfections such as asymmetric information. Nevertheless, there have been improvements in the Mauritian financial market triggered by policies implemented by relevant institutions post 2006. As a matter of fact, since 2008, the SEM has become a public company and in 2010 it started pursuing an internationalization strategy by revisiting its listing framework and rules. In addition since 2010, the SEM has undergone a strategic reorientation transitioning from an equity based local exchange to a multi-product exchange with an international outlook. By the end of 2013, the SEM has also reduced its transaction fees. The reduction in trading fees is expected to boost the volume of activity on the SEM overtime and to promote efficient trading on the exchange and in the same vein improve liquidity.

While the adjustments costs are lower and highlight a quicker adjustment process when analyzed on a comparative basis (against the period covered by Seetanah et al. (2007)), they remain high when viewed in isolation. A rational explanation behind the low adjustment speed is probably because Mauritian companies face low transaction costs when it comes to borrowing money from banks. Miguel \& Pindalo (2001) postulate that such type of funding (bank loans) is associated to lower agency costs between creditors and shareholders. In addition, for the period under study, especially 2008 and onwards, with the spillover effects of the global financial crisis, the Mauritian economy demonstrated resilience by recording stable growth rates but the growth rates were unspectacular and lower than expected. The level of investment was lower at that time and firms perhaps relied on internal earnings and debt as their main sources of financing. Foreign investors selling their shares did not do the Mauritian equity market any favors either and further discouraged new issues of shares. Empirical studies conducted by Choe et al. (1993), suggest that when the economy is not performing well, equity issues tend to be low while they tend to high in periods of good economic performance. This is consistent with the market timing hypothesis. Equity issues as such may have been hampered by the global financial crisis.

The dynamic panel table also reports a positive and significant coefficient of stock market development index for the aggregate sample except for financial companies where an insignificant association is highlighted. The positive and significant coefficient implies that further expansion in the market has generated opportunities for risk-sharing and the aggregation of information which has encouraged firms to increase their borrowing. These results are in line with Demirguc-Kunt \& Maksimovic (1996) and Seetanah et al. (2007) but are in contradiction with the findings of Agarwal \& Mohtadi (2004) and Joeveer (2006). It should be noted that further expansion in the banking sector is also related with an increase in the leverage ratio of non-financial firms. De facto, the expansion of equity markets has encouraged non-financial firms to take more loans. Equity and debt financing are, in essence, imperfect substitutes in countries with developing stock markets (Demirguc-Kunt and Maksimovic, 1996). The development of the stock market has supported the growth of the banking sector and this has had a deflationary pressure on the costs of both equity and debt. It can be thus inferred that the new investment boosted by stock market expansion has been partly funded by new bank loans especially for non-financial firms.

At the current stage of development of the SEM, equity issues are considered as complements rather than replacements for bank lending and this is especially relevant for non-financial companies. The banking sector index is insignificant in explaining the capital structure of financial firms and the aggregate sample though. This lack of significance for the aggregate sample and financial firms can be attributed to the fact that some of the listed financial companies did not register any long term liabilities on their financial statements for years and banks are the primary sources of long term loans. This may also be because financial firms need to be more careful about the extent of the financial risk on their balance sheets and being well-capitalized is also a necessity.

To achieve the objective of this paper, the regression equation is also estimated using random coefficient estimates (RC) and the results are depicted in Table 5. 
Table 5. Random Coefficient Estimates

\begin{tabular}{|c|c|c|c|}
\hline Predictors & Coefficients & Std. Error & P-value \\
\hline Size & .0440336 & .009657 & 0.000 \\
\hline Growth & .0495337 & .0213982 & 0.021 \\
\hline Risk & .1192203 & .1181988 & 0.313 \\
\hline Tangibility & -.2579887 & .0617097 & 0.000 \\
\hline Age & -.0320021 & .0418246 & 0.444 \\
\hline Liquidity & -.0023836 & .0010121 & 0.019 \\
\hline Profitability & -.2537499 & .0668859 & 0.000 \\
\hline Bank Index & .0019681 & .0460262 & 0.966 \\
\hline Stock Index & .0952164 & .060472 & 0.015 \\
\hline Constant & -.1482131 & .2072885 & 0.475 \\
\hline
\end{tabular}

\section{Wald Test:}

Wald $\chi 2(9)=67.64$

Prob $>\chi 2=0.0000$

Source: Stata 12

Using the random coefficient estimates framework allows the discovery of new relationships between the chosen determinants and new paths in behavior. The RC estimates report risk and age as being unimportant in explaining capital structure decisions of all the listed SEM firms. The insignificance of risk and age can be explained by the fact that Mauritian banks probably put more emphasis on other key determinants in the assessment of firm's creditworthiness. Indeed, Mauritian banks place more emphasis on collateral assets as a guarantee against default payments.

Nevertheless, growth opportunities are reported as a significant determinant which is contradictory to the GMM estimates. The RC estimates also suggest that banking sector index is insignificant given its p-value of 0.966 for the whole sample and highlight a positive and significant relationship between stock market development and debt-equity ratios which is in line with the dynamic panel data results. The signs of the random coefficients are consistent with the results reported by the dynamic panel data estimates even if the level of statistical significance may differ. The signs of the correlation coefficients of growth opportunities and profitability support the Pecking order hypothesis while the negative correlation coefficient of size is in accordance with the trade-off theory. The negative correlation reported for tangibility is inconsistent with the trade-off theory and Pecking order theory.

An advantage of the Wald test is that it can be used to test multiple parameters at the same time. The Wald test measures the overall significance of the regression. The p-value is less than the generally used criterion of 0.05 and thereof we can reject the null hypothesis, suggesting that the coefficients are not simultaneously equal to zero. Thus, the Wald test hints at a fine goodness of fit.

\section{Conclusion}

On a concluding note, the paper employs dynamic panel data econometric techniques such as GMM coupled with the random coefficient framework to investigate the determinants of capital structure decisions. The results reveal that both empirical and theoretical studies are to some extent relevant in the Mauritian context. The study reveals that while in some cases the trade-off theory is pertinent, there is other firms' financing behavior which can be better explained by the Pecking order theory. The Mauritian equity market has witnessed important transformation and development post 2006 but it is still at a developing stage as portrayed by the positive relationship identified between debt and stock market development. The other main explanatory variables of capital structure in Mauritius for the aggregate sample according to random coefficient estimation are profitability, tangibility, liquidity, and growth while banking sector development, age and risk are found to be impotent in general. GMM results report age as being a significant variable and growth opportunities to be unimportant in explaining financing decisions of the whole sample. A significant and positive relationship between banking sector development and financing decisions is also highlighted for non-financial companies only. The results from this study have important insights to offer. A potential limitation of this paper is that it covers a relatively new period that is 2006-2014. In order to gain a more general insight one could use the period 
1989-2015 since the Stock Exchange of Mauritius (SEM) was set up in 1989.

Since the Mauritian debt market is relatively under-developed, firms normally have a preference for short-term debts such as trade credit as it constitutes one of the cheapest sources of funding and there are no material costs attached. Debentures, bonds, bills and notes are other components of the debt market left unexploited. The SEM and the Bank of Mauritius (BoM) have shown strong willingness to boost the secondary market liquidity for debentures and a blunt assessment would be that listing debentures mainly on the SEM has not really helped in this regards. This is because bonds are normally traded in large blocks in over-the-counter (OTC) markets. To boost liquidity of government securities in secondary markets, the BoM should inspire itself from international modus operandi and force all primary dealers to quote daily firm bids and offers on the traded government securities to improve transparency. When it comes to the fundamental role of the private financial sector, the prerogative of being part of the bidding parties for government securities and earning profits in distributing the financial instruments should constitute an impetus for enhanced cooperation. Even institutions not necessarily detaining a primary dealer license could be given the freedom to act as market-maker in the secondary market for government securities.

Moreover, legal and operational hassles for short-selling and securities lending should be eradicated on the stock market. In addition to enhancing secondary market liquidity for government bonds, allowing short-selling should lead to an active repo market which is an important ingredient for collateralized financing where holders of government securities are concerned. The prevailing legal and operational imbroglio in Mauritius for acquiring collateralized financing has to be greatly simplified by adopting standardized international guidelines for repo transactions.

The SEM could carry on offering a facility to list and trade debentures for smaller issuers mainly alongside OTC markets and act as a gatherer and disseminator of transaction data for the OTC bond market. The enhanced secondary market liquidity will generate a vibrant government yield curve and this will give price signals to economic agents, aid in the proper valuation of government securities holdings and act as a benchmark for pricing other debt instruments. After the underpinning of a well-functioning secondary government bond market is established, alternative debt capital markets should develop on its basis. The embryonic corporate bond market which is our primary concern will receive more incentive, and new markets might ultimately see the day. In regards to equity markets, global trends postulate that equity markets grow hand in hand with the economy. The limited size of Mauritius means the domestic economy tends to restrict the growth of equity markets and this is how internationalization comes into the equation. This strategy is already in place since 2010 but we recommend policy makers (the SEM) to amplify their efforts in regards to internationalization. All these changes in regards to financing options can ultimately exert a deflationary pressure on the cost of capital in general which will be optimum for listed Mauritian firms. Firms which favour the Pecking order theory rely on internal finance and such companies are recommended to issue low level of dividends which will keep their retained earnings level higher.

\section{Acknowledgement}

We applied the EC approach for the sequence of authors. We would like to thank Ganessen Chinnapen for his opinion. Our sincere gratitude goes to M. Lundell and S. Alexis for their most valuable comments. Funding: We would also like to thank Thavendra Koomarsing Gourdeale for funding this paper.

\section{References}

Abor, J. (2005). The effect of capital structure on profitability: an empirical analysis of listed firms in Ghana", The Journal of Risk Finance, 6(5), 438-445

Afolabi, J. K., Appiah, K.O. \& Boakye, P.K.O. (2013) Determinants of capital structure: Evidence from Ghanaian firms, Research Journal of Finance and Accounting, 4(4), 44-52.

Agarwal, S., \& Mohtadi, H. (2004). Financial Markets and the Financing Choice of Firms: Evidence from Developing Countries, Global Finance Journal, 15(1), 1-14.

Baker, M., \& Wurgler, J. (2002) Market Timing and Capital Structure. Journal of Finance, 57, 1-32.

Baral, K. J. (2004) Determinants of capital structure: A case study of listed firms in Nepal, The Journal of Nepalese Business Studies, 1(1), December, 1-13.

Bheeroo, M. (2012) The impact of financial leverage on investment decisions for firms listed on the official market of stock exchange of Mauritius. BSc. Thesis, University of Mauritius, 72.

Chen, J.J. (2004). Determinants of Capital Structure of Chinese listed companies', Journal of Business Research, 57, 1341-1351.

Cortez, M., \& Susanto, S. (2012) 'The determinants of corporate capital structure: Evidence from Japanese manufacturing companies', Journal Of International Business Research, 11, 122-134, Business Source Complete, EBSCOhost, [Accessed 21 September 2015] 
Demirguc-Kunt, A., \& Maksimovic, V. (1996). Stock market development and corporate finance decisions, Finance \& Development, 33(2).

Demirguc-Kunt, A., \& Maksimovic, V. (1996). Stock Market Development and Financing Choices of Firms. The World Bank Economic Review, 10(2).

DungThuyThi, N., Diaz-Rainey, I., \& Gregoriou, A. (2014) 'Determinants of the Capital Structure of Listed Vietnamese Companies', Journal of Southeast Asian Economies, 31(3), 412-431, Business Source Complete, EBSCOhost,[Accessed 21 September 2015]

Factbook (2014, 2015). Stock Exchange of Mauritius Ltd, Port-Louis.

Giannetti, M. (2003). Do better institutions mitigate agency problems? Evidence from Corporate Finance Choice. Journal of Financial And Quantitative Analysis, 38(1), 185-212.

Handbook (2010, 2014, 2015). Stock Exchange of Mauritius Ltd, Port-Louis.

Hondroyiannis, Swamy, P. A. V. B., George, S. T., \& Ulan, M. (2005) 'Some Further Evidence on Exchange Rate Volatility and Exports', Working Paper, 28, Bank of Greece.

Jahanzeb, A., Rehman, S., Bajuri, N. H., Karami, M., \& Ahmadimousaabad, A. (2013) 'Trade-Off Theory, Pecking Order Theory and Market Timing Theory: A Comprehensive Review of Capital Structure Theories,' International Journal of Management and Commerce Innovations (IJMCI), 1(1), 11-18.

Koch P. (2014). 'Reforming financial markets in Mauritius', Bilingual Journal of PluriConseil, 67, 1-14.

Mauritius in Figures (2006-2014). Statistics Mauritius, Port-Louis.Mauritius', International Business \& Economics Research Journal, 10(3), 1-14

Modigliani, F., \& Miller, M. H. (1958) 'The cost of capital, corporate finance and the theory of Investment', The American Economic Review, 48(3), 261-297.

Odit, M. P., \& Gobardhun, Y. D. (2011) 'The Determinants of Financial Leverage of SMEs.

Onaolapo, A. A., Kajola, S. O., \& Nwidobie, M. B. (2015) 'Determinants of capital structure: A study of Nigerian quoted companies', European Journal of Business and Management, 7(23), 170-183.

Padachi, K., \& Seetanah, B. (2007). 'Stock Market Development and Financing Choices of firms: A Case Study of SIDS', International Review of Business Research Papers, 3(2), 305-325.

Padaruth, M. P. (2014). Capital structure decisions adopted by listed firms on SEM. BSc. Thesis, University of Mauritius, 63.

Ramlall. I. (2009). 'Determinants of Capital Structure Among Non-Quoted Mauritian Firms Under Specificity of Leverage: Looking for a Modified Pecking Order Theory', International Research Journal of Finance and Economics, 31, 1-10.

Sangeetha, M., \& Sivathaasan, N. (2013). 'Factors determining capital structure: A case study of listed companies in Sri Lanka', Research Journal of Finance and Accounting, 4(6), 1-12.

Seetanah, B., Seetanah, B., \& Padachi, K. (2007). 'On the dynamic relation between Stock Market Development and Capital Structure of firms: Evidence from a developing country,' School of Economics, Finance and Marketing, RMIT University.

Seetanah, B., Seetah, K., Appadu, K., \& Padachi, K. (2014). 'Capital Structure and firm performance: Evidence from an emerging economy', The Business and Management Review, 4(4), March, 185-196

Tiwari, A., \& Krishnankutty, R. (2015).Determinants of capital structure: A quantile Regression analysis', Studies In Business \& Economics, 10(1), 16-34, Business Source Complete, EBSCOhost, [Accessed 21 September 2015]

World Bank. (2015) Domestic credit to private sector (\% of GDP) data table, [ONLINE] Available at: http://data.worldbank.org/indicator/FS.AST.PRVT.GD.ZS. [Accessed 20 December 2015]

World Bank. (2015) Liquid liabilities (M3) as \% of GDP data table, [ONLINE] Available at: http://data.worldbank.org/indicator/FS.LBL.LIQU.GD.ZS [Accessed 20 December 2015].

World Bank. (2015) Stocks traded turnover ratio of domestic shares (\%) data table, [ONLINE] Available at: http://data.worldbank.org/indicator/CM.MKT.TRNR [Accessed 22 December 2015].

\section{$(\mathrm{cc}) \mathrm{BY}$}

This work is licensed under a Creative Commons Attribution 3.0 License. 